\title{
UNDERSTANDING THE EFFECTS OF TIME MANAGEMENT AND SELF-EFFICACY ON MATH PERFORMANCE AMONG HIGH SCHOOL STUDENTS WORKING PART-TIME IN CEBU, PHILIPPINES
}

\author{
Emerson D. Peteros ${ }^{1}$, Juvelyn T. Cañabano ${ }^{2}$, Domenic T. Sanchez ${ }^{3}$, Larry B. Peconcillo Jr. ${ }^{4}$, \\ Reylan G. Capuno ${ }^{5}$, Ramil P. Manguilimotan 6 , Gengen G. Padillo ${ }^{7}$, \\ Raymond C. Espina ${ }^{8}$, Lilibeth C. Pinili ${ }^{9}$, Janneka Fae C. Capuno ${ }^{10}$ \\ ${ }^{2}$ Bato National High School, Toledo City, Cebu \\ ${ }^{3,4}$ Cebu Technological University, Naga Campus, College of Education \\ 1, 5, 6, 7, 8, 9, 10 Cebu Technological University, Main Campus, College of Education \\ Iemerson.peteros@ctu.edu.ph,_juvelyn.canabano@yahoo.com,3domenic.sanchez@ctu.edu.ph \\ ${ }^{4}$ larry.peconcillojr@ctu.edu.ph, ${ }^{5}$ reylan.capuno@ctu.edu.ph, ${ }^{6}$ ramil.manguilimutan@ctu.edu.ph \\ 7gengen.pardillo@ctu.edu.ph, ${ }^{8}$ raymond.espina@ctu.edu.ph \\ ${ }^{9}$ lilibeth.pinili@ctu.edu.ph, ${ }^{10}$ jannekafae.capuno@ctu.edu.ph
}

\begin{abstract}
Although the government provides free education, poverty is one of Filipino students' most common challenges in their pursuit of basic education. To overcome financial constraints and to be self-sufficient while studying, high school students choose to find errands. In Toledo City, Cebu, Philippines, thirty-one public high school students working part-time were studied to find answers if there was a link between time management, self-efficacy, and academic performance, specifically, assessing the respondents' math performance, using the adopted survey questionnaire. The results revealed that they performed satisfactorily in math while practicing moderate time management and having moderate self-efficacy in the subject. There was no significant relationship between time management and math performance; however, self-efficacy and math performance had a significant weak positive correlation. As a result, teachers are encouraged to create programs that boost students' self-efficacy and time management abilities. It is strongly suggested that time management skills are integrated into the subjects to form and promote students' positive reactions. From the theoretical point of view, once the competencies have been learned and practiced, students are expected to manage, strive for, and fulfill their life objectives more effectively.
\end{abstract}

Keywords: time management, self-efficacy, working students, academic performance in Math.

\section{Introduction}

Education is a powerful tool for a person's success. It is regarded as a valuable asset that everyone possesses and which aids a person in achieving one's life objectives. As a result, this is one of the fundamental rights that every individual has, and no one can prevent anyone from obtaining an education. However, due to some of the constraints that limit this opportunity, obtaining this privilege is difficult. Some students are unable to meet the financial obligations of attending school. This is a problem that many Filipino high school students face, as some of them must work to meet their financial obligations while attending classes. Working while studying is a common practice among poor Filipino high school students.

Typically, they are forced to work while attending school because their parents cannot pay their tuition. They spend every day at school and the rest of the time after school working. For these students, maintaining a balance between studies and work is difficult. Priorities must be set to manage time effectively. Time management is a crucial aspect for these students to keep their priorities in life. Everyone has time, but few people use it effectively Pehlivan 2013 [31].

Students' performance at school and work will suffer if they fail to manage their time effectively. These students must schedule their time effectively to catch up on lessons, assignments, projects, and other school requirements. On the other hand, they must maintain good work performance to keep their jobs, as losing them would have a negative impact on their studies. Every person's ability to manage time is essential. Regardless of one's position in life, time management and utilization are equally important Sayari, 
Jalagat \& Dalluay 2017 [36]. To help support their studies, many students in the Philippines choose part-time jobs. They are hired as caregivers and household help primarily by their relatives and teachers. In exchange, they send them to school and provide financial support.

Though they are not required to work for long periods, work pressure may affect their school activities, particularly in subjects that most students consider complicated, such as mathematics. As a result of not having enough time to focus on their studies, their math performance may be compromised. If they can manage their work and study time; as a result, they may achieve their goals due to their ability to manage a hectic schedule. The competitive environment in which we all live today encourages people to plan and manage time effectively Mohamed, Hamal \&Mohamed 2016 [24].In this context, the researchers were encouraged to undertake the study to assess the connection between time management, self-efficacy, and mathematics performance of the high school students working part-time.

\section{Related Literature And Studies}

The study is based on Abraham Maslow's Theory of Time Management, which focuses on understanding one's needs, the ability to differentiate these needs, and the time spent on completing tasks so that these activities do not overlap with other important aspects of one's life. Working students' lives are inextricably linked to their ability to manage time for both work and studies effectively. Students must concentrate on their studies to improve their grades. They cannot, however, devote all of their time to studies because they must support themselves. They should be able to focus on their work because their job will help them continue their studies. Poor school performance may result from failure to strike a balance between work and studies. As a result, they must assess whether they can effectively manage their time to perceive themselves as efficient students. While efficiency refers to the proper execution of specific tasks, effectiveness refers to selecting the right job to be done well Mohamed, Hamal \& Mohamed 2016 [24].

Furthermore, Albert Bandura's self-efficacy theory 1995 [7] explains how one's belief in the ability to plan and execute the actions required to manage future situations. As working students, they must effectively manage their time between work and studies. How well they manage their time determines their self-efficacy. Students working part-time may devise strategies to balance their time between work and studies to survive this situation.

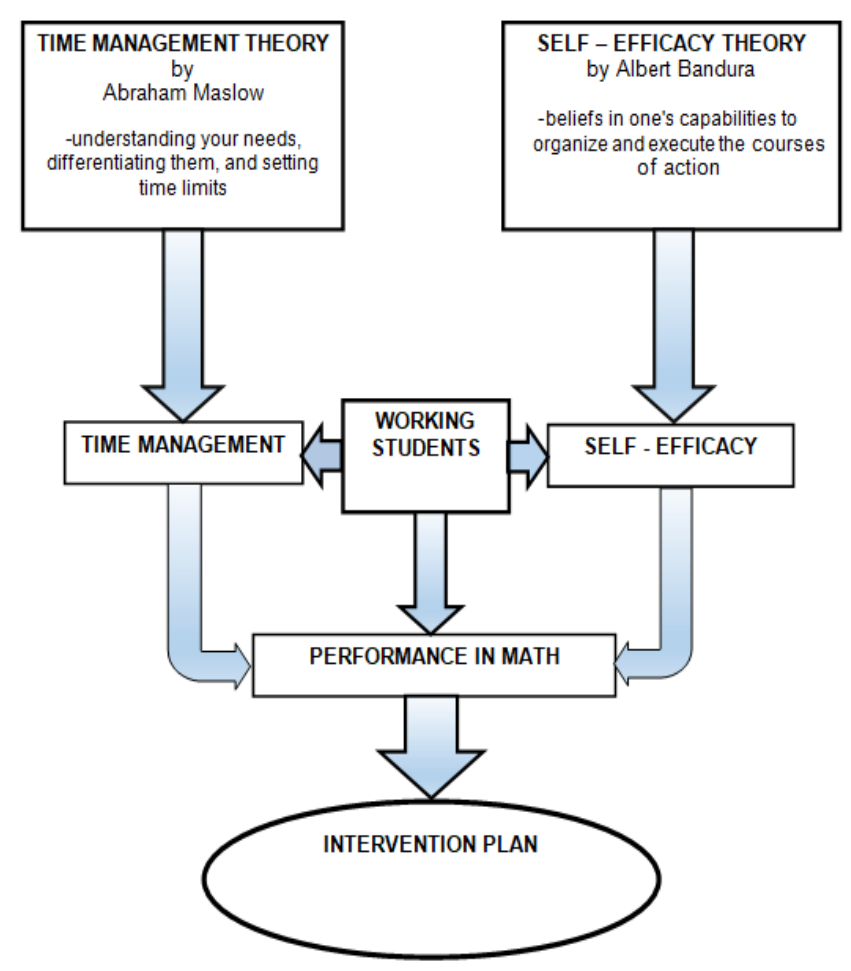

Figure 1. Conceptual Framework

\subsection{Time Management}

Time management is a collection of ideas, philosophies, rules, practices, abilities, instruments, and schemes that work together to help people get the most out of their time Gerard 2002 [13]. Because time cannot be stored and its availability cannot be increased or decreased from twenty-four hours, time management structures the distribution and delivery of timebased priorities among competing demands Khanam et al. 2017 [15]. The individual's initial self-recognition, knowledge of his or her characteristics, examining the problem of time use and collecting relevant information, evaluating elective arrangements, selecting and updating one of these choices are all part of the time management process Iz \& Ozen 2010 [11]. When a person is committed to overcoming procrastination, he can manage time well Quek 2001 [32]. Students must learn to manage time effectively to improve their grades Brigitte et al. 2005 [9]. As a result, every student should have time management skills to organize tasks effectively, identify goals, and focus on improving tasks that require immediate attention over others. Students' ability to make decisions could be improved by using time Noftle, Robins \& Richard 2007 [29]. One of the best signs of achieving outstanding academic performance has been time management procedures. Using time management techniques improves academic performance Fazal 2012 [12]. Attending classes on time and meeting project and assignment deadlines are critical responsibilities for students who want to improve their grades. While people in offices, colleges, and other facilities value time differently, employees and students should observe and follow standard time Sayari, Jalagat \& Dalluay 2017 [36]. 


\subsection{Time Management and Academic Performance}

According to Mercanlioglu 2010 [20], students who used time-saving techniques excelled academically. Students who did not use time-saving techniques in their school assignments performed worse academically. Prioritization, procrastination, and socialization are three variables that some time management researchers consider when describing the structure, and they may impact students' performance. Because they cannot organize things, students face issues such as disliking their responsibilities and uncertainty, so they defer their responsibilities. As a result, they will struggle to manage their tasks following their distracting and procrastinating priorities Mohamed, Hamal, and Mohamed 2016 [24]. Priority is a significant predictor of students' better academic performance, according to Sayari, Jalagat, and Dalluay 2017 [36], but procrastination and socialization have no bearing. Rai 2016 [33] discovered that students who receive lower grades are not necessarily less capable than their peers but typically receive lower grades in exams due to time management issues. According to Sabelis 2001 [34], students can use time efficiently and competently by organizing their tasks, prioritizing their goals and responsibilities, making a list of activities to do, and organizing their workspace. Because some students lack time management, resort to procrastination, and are unable to meet school deadlines, Quek 2001 [32] believes that procrastination and prioritization are the most common problems of students on time management. According to Kearns and Gardiner 2007 [14], students struggle with prioritization because they lack a clear direction in their studies, are easily distracted and disorganized in their assignments, and cannot plan and prioritize tasks. Finally, Knaus 1996 [16] stated that students might be amazed by their responsibilities to the point where they postpone schoolwork, spend more time hanging out with friends, or worry about the upcoming examination, class project, and papers rather than finishing them. Abedayo 2015 [2] investigated the vital relationship between time management and the three variables of prioritization, procrastination, and socialization among 200 students in Nigeria's Higher Education Institutions. Between these three variables, he discovered a significant relationship between the students' academic performance. As a result, it was suggested that students should limit their time spent on social activities because their academic performance will suffer. Spending more time on social events would have a more significant impact on their academic activities. Procrastination is a problem that affects everyone, and everyone experiences it in some form or another at some point in their lives, though the severity of procrastination varies from person to person. The truth is that everyone has a habit of daydreaming and not respecting time, but some people do so to the point where they neglect essential tasks. Students may be cautious of postponing activities or assignments regularly, as this can make their job more difficult and affect their performance. In terms of prioritization, the study found that students lack a goal-setting strategy that impacts their performance because objectives are not organized or completed due to importance and urgency. Finally, there was no significant difference in the impact of time management on academic performance based on gender, implying that both sexes use their time equally. These results were consistent with Adebayo's study 2015 [2], which concluded that time management affects both male and female students. To improve their academic performance, students should observe and consider prioritizing their tasks and responsibilities Sayari, Jalagat \& Dalluay 2017 [36].

Pehlivan's 2013 [31] study of financial accounting students found that female students have higher time management skills scores than male students. Besides, there was a significant positive correlation between the sub-dimension of time attitudes and the students' grade point averages (GPA). Finally, time management skills impact the accomplishment of the students' GPA course, which is one of the predictors of their GPA and grade points in financial accounting. According to Miqdadi et al. 2014 [21], time management is heavily linked to Petroleum Institute students' academic performance. They further concluded that successful students are good managers of time.Misra and McKean 2000 [23] examined the relationship between time management and leisure satisfaction by age and gender among 249 university undergraduate students who found that women had better time management skills compared to their male counterparts (perceived better time control, set and prioritized goals, planning and had an organized approach to tasks and workspace). However, Saketi and Taheri 2010 [35] found no significant difference in male and female students' time management skills, but female students performed better than males. They argued that time management skills were consistent with differences in academic achievement scores and suggested that students be trained in time management skills to improve their achievements.

Misra \& Mckean 2000 [23] found that gender and time management are significantly correlated, where women engage in more mechanical time between gender and time management. The findings of Sevari \& Kandy 2011 [39] on 293 students showed that, compared to their male counterparts, female students could manage their time more effectively. Besides, older students were found to be better able to manage their time than the younger ones, in which these abilities are significant predictors of their academic performance. The study of Tanriogen and Iscan 2009 [44] on the effects of time management attitudes and skills on academic performance among Pamukkale University students found that students have moderate time management skills, while only a few have high management skills. Also, time management abilities are significantly related to their 
academic performance, while the students' time management skills can predict 7.9 percent of the academic performance.

Similarly, one of the factors affecting students' performance in school is managing time Al-Khatib 2014 [4]. Poor time management can lead to poor academic results, while efficient time management can lead to higher academic performance levels Balduf 2009 [6]. The relationship between time management behavior and the GPA of the 271 students attending sports management programs at Gazi, Muğla, and Atatürk Universities was investigated by Yilmaz, Yoncalik, and Bektas 2010 [45].

It was established that the students' time management behavior and GPA did not have a significant relationship. Also, these abilities had no impact on the respondents' age and gender. Furthermore, Swart, Lombard, and Jager 2010 [43] justified the African engineering students' academic performance showed no significant connection between time management and the respondents' academic performance. Besides, female students have less time-based achievement compared to male students, but female students use time more efficiently than their counterparts, such as making a list, designing a plan, and making a program for all the activities they are engaged in Alay \& Koçak 2003 [3]. Finally, time management training has improved students' academic performance and selfefficacy Sevari \& Kandy 2011 [39].

\subsection{Self-efficacy}

Self-efficacy is students' perception of their ability to enhance new abilities specific to certain academic fields Nasiriyan et al. 2011 [27]. According to Brahier 2009 [8], self-efficacy refers to the extent to which students perceive their ability to succeed in the tasks given. If a student is not successful in a mathematics class based on experience and encounters a problem that is not necessarily difficult, a student is likely to think, "I can't do this," and may give up almost immediately. The student believes that the work would be challenging to complete successfully because of his inability to do the task. On the other hand, the student's choice of activities is influenced by self-efficacy Schunk \& Pajares 2002 [37]. Students with low self-efficacy may avoid many learning tasks and activities, while students with high self-efficacy approach these learning tasks enthusiastically. In doing the learning task, students with high self-efficacy are more likely to persevere with effort than students with low self-efficacy. The belief that an individual has that they can effectively perform the actions needed to achieve the intentions is self-efficacy. Self-efficacy can be viewed as one's perceptions of competence and their chances of accomplishing a specific task. Self-efficacy, however, can change based on one's data, experiences, and learning Schwoerer et al. 2005 [38]. Besides, as applied to work, self-efficacy describes the person's trust in his or her ability to perform the task along with his or her belief that he or she can perform specific tasks effectively in a particular situation Stajkovic \& Luthans 1998 [42].

\subsection{Self-efficacy and Academic Performance}

Among 180 Albanian students from two selected universities in Tirana, Albania, Shkullaku 2012 [40] explored the major gender differences in self-efficacy and academic performance. It was found that there was a significant difference in selfefficacy between men and women, but no significant difference in academic performance was found between men and women. Also, there was a significant relationship between the students' self-efficacy and academic performance. Shkullaku 2012 [40] discussed that students' beliefs about their self-efficacy were very influential variables on whether, despite their difficulty, they will make an effort on the task and continue. Students with a high level of self-efficacy would attempt to do the assignments and continue to try; although the task is difficult, the students' low level of self-efficacy would usually give up easily. This finding was endorsed by Pajares 2000 [30], who concluded that students with firmer beliefs in self-efficacy perform better with their academic performance, not like low-performing students who are reluctant to perform the tasks they consider difficult because of their lack of beliefs and success skills.

Furthermore, Nasiriyan et al. 2011 [27] stated that, compared to students with low self-efficacy, students with high selfefficacy tend to engage in challenging tasks, provide more effort and persistence, and exhibit excellent academic performance. Mousoulides \& Philippou 2015 [25] found a positive relationship between self-efficacy and academic achievement and that if they undergo training to have greater self-efficacy, students' academic performance will improve. Koseoglu 2015 [17] argued that "students with low selfefficacy were inclined to believe that intelligence is inherent and cannot be changed" while students with high self-efficacy prefer to master the tasks and like to be challenged with their performance, which when it comes to performing their duties is very competitive. Therefore, students with high self-efficacy were able to compose and master their feelings in the face of the challenges they encountered that led to their academic excellence. Abouserie 1995 [1] noted that students who believe that intelligence can be changed and modified by their efforts have high self-efficacy and trust in their academic performance.

Miller \& Brickman 2004 [22] noticed that students 'higher self-confidence is linked to their high academic performance, which encourages them to accept greater responsibility to complete the assignment successfully. Lane \& Lane 2001 [18] reported that one of the predictors in an academic setting found that self-efficacy predicts 11.5 percent of the performance of students, while Liu and Koirala 2009 [19] examined whether self-efficacy in mathematics is significantly related to the achievement of Grade 10 students in 
mathematics and the predictability of math performance through their self-efficacy.

The results showed that self-efficacy is positively correlated with their achievement in mathematics. Besides, the regression analysis showed that self-efficacy significantly predicts the achievement of students in mathematics. Interestingly, the relationship between math self-efficacy and math performance in 352 senior high school students in Oyo State was explored by Ayotola and Adedeji 2009 [5]. No significant gender difference was found between self-efficacy and performance in mathematics. With the various literature and studies cited, no study on the time management and self-efficacy of working students was conducted. The researchers would like to explore the connection between time management, self-efficacy, and high school students' academic performance to address the gap in time management and self-efficacy of working students between the unexplored areas that need to be understood explained.

\subsection{Statement of the Null Hypotheses}

Based on the objectives of the study, the following assumptions were put to the test at a level of 0.05 significance:

Ho1: There is no significant relationship between time management and math performance of the respondents.

Ho2: There is no significant relationship between self-efficacy and math performance of the respondents.

\section{Methodology}

The study used a descriptive correlational research design that used the adopted questionnaire to determine the respondents' time management relationship, self-efficacy in learning mathematics, and academic performance. A descriptive correlational study aims to "describe the variables and the relationships that occur between and between them naturally Sousa, Driessnack \& Mendes 2007 [41]. Instead of determining the cause-effect relationships, the correlational research design is used to explore the nature of the relationship or association between and among the variables involved in the study. In Toledo City, Cebu, Philippines, a take-all sample was used to determine the study respondents at a Public National High School. The 31 high school students working to make money while studying were the focus of this study. They are called working students who need to manage their time to fulfill school and work demands effectively. With the type of life they have as students, their perception of their effectiveness in learning math has been evaluated. The Time Management Survey Questionnaire Sayari, Jalagat \& Dalluay 2017 [36] and the Self-Efficacy Survey were used in two adopted survey questionnaires Nicolaidou \& Philippou 2003 [28]. Also, with their respective advisers' assistance, the respondents' academic performance was determined using data mining.

\section{Results And Discussion}

This portion exhibits the results based on the data gathered about the objectives of the study.

Table1. Performance Level of the Respondents $(n=31)$

\begin{tabular}{|c|c|c|c|}
\hline Level & Numerical Rating & $f$ & $\%$ \\
\hline Outstanding & $90-100$ & 4 & 12.90 \\
\hline Very Satisfactory & $85-89$ & 7 & 22.58 \\
\hline Satisfactory & $80-84$ & 12 & 38.71 \\
\hline Fair Satisfactory & $75-79$ & 8 & 25.81 \\
\hline Did not meet the Expectations & Below 75 & - & - \\
\hline Total & & 31 & 100.00 \\
\hline Average & 83.06 & & \\
\hline
\end{tabular}

As reflected in Table 1, all of the respondents had passed in Math. Although there were students who had an excellent performance, it is still needed to improve their performance, especially those who had a satisfactory and reasonably satisfactory performance. Appropriate intervention can be implemented to prevent respondents' performance from declining. Factors that could affect students' performance can be looked into to address the right problem. In this study, the student's time management and self-efficacy are the variables considered that could affect students' performance. Students with part-time jobs are expected to have lower academic performance because their focus time is divided by their working time. Better academic performance is only achieved when students spend more time on school-related activities outside Muluk 2017 [26].

Table 2. Time Management of the Respondents in terms of prioritization $(n=31)$

\begin{tabular}{llcc}
\hline \multicolumn{1}{c}{ Indicators } & $\overline{\boldsymbol{x}}$ & sd \\
\hline $1 \quad \begin{array}{l}\text { I plan out my daily duties with the right } \\
\text { strategy }\end{array}$ & 4.26 & 0.631 \\
$2 \quad \begin{array}{l}\text { I prepare a list of my tasks to be performed in } \\
\text { sequential order. }\end{array}$ & 2.87 & 1.088 \\
$3 \quad \begin{array}{l}\text { I see to it that I prioritize the task according } \\
\text { to what should be the first to be done. }\end{array}$ & 3.71 & 1.071 \\
$4 \quad \begin{array}{l}\text { I set enough time for my daily duties } \\
\text { activities. }\end{array}$ & 3.94 & 1.063 \\
$5 \quad \begin{array}{l}\text { I check the accomplishments of my tasks } \\
\text { based on the priorities made. }\end{array}$ & 4.23 & 0.497 \\
$6 \quad \begin{array}{l}\text { I monitor my daily activities by comparing } \\
\text { my plan against what has been actually done } \\
\text { and reconcile any differences. } \\
\text { Overall Weighted Mean } \\
\text { Overall Standard Deviation }\end{array}$ & 3.61 & 1.145 \\
\hline
\end{tabular}

The students can set priorities in their studies to put more important things in the list of activities they have to accomplish for the day. Moreover, they can spend more time on those activities relevant to their studies to better school performance.

Table 2 shows the statements describing the time management of the respondents as to their prioritization of things. In general, the overall weighted mean of 3.77 and a standard deviation of 0.916 indicate that the respondents prioritized 
things. A good time management practice prioritizes things according to their importance and relevance to the person's status. Those that are more important things are given more priorities, and more time will be allocated for these things to ensure that whatever is the desired outcome of such things will be achieved. Just in the working students' case, their main priority in life should be their studies, and thus they should spend more time accomplishing tasks required in school. However, they should not also take for granted whatever their works are outside the school because this helps them sustain their studies. It is important to balance their time towards their studies and their work so that none of the two will be compromised. Not all tasks have the same importance, wherein the most important tasks should be given the most priority Dinkel 2011 [10]. These tasks should be allocated with more attention, energy, and time. Prioritization provides the individual with the chance to spend more time on the most important things.

Table 3. Time Management of the Respondents

\begin{tabular}{|c|c|c|c|}
\hline & Indicators & $\overline{\boldsymbol{x}}$ & sd \\
\hline 1 & $\begin{array}{l}\text { I always say that there is still } \\
\text { enough time to finish my tasks. }\end{array}$ & 4.13 & 0.846 \\
\hline 2 & $\begin{array}{l}\text { I cancel my tasks without valid } \\
\text { reasons. }\end{array}$ & 2.81 & 0.910 \\
\hline 3 & $\begin{array}{l}\text { I am not in a hurry to finish my } \\
\text { scheduled tasks. }\end{array}$ & 3.52 & 1.235 \\
\hline 4 & $\begin{array}{l}\text { I always ask for an extension of } \\
\text { my assignment submission. }\end{array}$ & 3.16 & 1.344 \\
\hline 5 & $\begin{array}{l}\text { I love playing computer games, } \\
\text { even it delays task compliance. }\end{array}$ & 2.26 & 1.460 \\
\hline 6 & $\begin{array}{l}\text { I ignore deadlines and have } \\
\text { submitted assignments on time. }\end{array}$ & 2.94 & 1.315 \\
\hline 7 & $\begin{array}{l}\text { I study my lessons usually a few } \\
\text { days before the examination. }\end{array}$ & 3.65 & 1.226 \\
\hline \multirow[t]{2}{*}{8} & $\begin{array}{l}\text { I don't mind being late as long } \\
\text { as I will be there during classes. }\end{array}$ & 3.94 & 1.436 \\
\hline & $\begin{array}{c}\text { Overall Weighted Mean } \\
\text { Overall Standard Deviation }\end{array}$ & 3.30 & 1.221 \\
\hline
\end{tabular}

Accomplishing the tasks which need to be done at the proper time without delaying it is an essential aspect of time management. The statements describing the procrastinations that the respondents could practice can be gleaned in Table 3 . With an overall weighted mean of 3.30 and an overall standard deviation of 1.221 , procrastination had been moderately practiced by the respondents. As working students, these respondents have limited time for accomplishing tasks in school because they have other responsibilities outside the school. So, it is imperative to do the given tasks in school as early as possible. Delaying their tasks for another day will have adverse effects on their performance in school. Managing one's time effectively can help one control his workload, increase one's productivity and improve one's confidence which would result in a lesser inclination to procrastinate and will be able to enjoy a healthy and balance studying and other activities Sousa, Driessnack \& Mendes 2007 [41].

With the limited time these respondents have, it is also essential to check if they still have time to spend time with their friends. Spending time with friends is a way of reducing ones' stress in school. As observed in Table 4, the overall weighted mean of 2.53 and an overall standard deviation of 1.093 mean that the respondents had less time practicing these socialization activities. With the hectic schedules that these respondents have, they will not have enough chance to spend their time with their friends because instead of spending time with friends, they will utilize their free time on doing school assignments and projects. When at home, they have to do the house chores assigned to them. Thus, socializing with their friends is minimized. However, every student should have time management to get rid of those fundamental problems related to time management, such as too much time spent on social networking sites and no definite schedule on any upcoming activities.

Table 4. Time Management of the Respondents in terms of socialization $(n=31)$

\begin{tabular}{|c|c|c|c|}
\hline & Indicators & $\bar{x}$ & sd \\
\hline 1 & $\begin{array}{l}\text { I spend more time texting and } \\
\text { chatting with friends. }\end{array}$ & 2.29 & 1.189 \\
\hline 2 & $\begin{array}{l}\text { I do browsing and chatting on } \\
\text { Facebook, Twitter, etc. }\end{array}$ & 2.65 & 1.142 \\
\hline 3 & I go to parties with my friends. & 2.13 & 1.118 \\
\hline 4 & $\begin{array}{l}\text { I spend more time networking } \\
\text { and meeting new friends. } \\
\text { I get involved in physical }\end{array}$ & 2.58 & 1.025 \\
\hline 5 & $\begin{array}{l}\text { activities in the gym and other } \\
\text { exercises. } \\
\text { I am actively involved in }\end{array}$ & 2.90 & 1.300 \\
\hline 6 & $\begin{array}{l}\text { weekend activities with my } \\
\text { family. }\end{array}$ & 3.65 & 1.170 \\
\hline 7 & $\begin{array}{l}\text { I regularly get involved with } \\
\text { religious activities. } \\
\text { I am spending more time in }\end{array}$ & 3.55 & 1.060 \\
\hline 8 & $\begin{array}{l}\text { shopping malls } \\
\text { hypermarkets. }\end{array}$ & 2.06 & 0.964 \\
\hline 9 & $\begin{array}{l}\text { I watch movies in Cinemas and } \\
\text { Theaters. } \\
\text { I spend time in playhouses }\end{array}$ & 1.52 & 0.851 \\
\hline 10 & $\begin{array}{l}\text { located in shopping malls and } \\
\text { others. } \\
\text { Overall Weighted Mean } \\
\text { Overall Standard Deviation }\end{array}$ & 2.53 & 1.110 \\
\hline
\end{tabular}

The respondents being in the situation where they have to work, and study is in a condition where they have to consider that they should be useful in their studies even though their time is divided. Data in Table 5 shows the overall weighted mean of 3.18 and an overall standard deviation of 1.002, which means that the respondents had moderate self-efficacy in learning mathematics. It is important to note that the respondents' perception of their self-effectiveness in learning mathematics needs to be improved. They feel that their studies' efforts are not yet enough because their time is divided, unlike other students who only focused their time on their studies. So, they feel that they have to double effort in school to perform better. To be proficient in this subject, one must frequently practice the mathematical skills introduced in the classroom. 
Table 5. Self-efficacy of the Respondents $(n=31)$

\begin{tabular}{|c|c|c|c|}
\hline \multicolumn{2}{|r|}{ Indicators } & \multirow{2}{*}{$\begin{array}{c}\overline{\boldsymbol{x}} \\
2.84\end{array}$} & \multirow{2}{*}{$\frac{\mathrm{sd}}{1.157}$} \\
\hline 1 & $\begin{array}{l}\text { I am one of the best students } \\
\text { in Mathematics. }\end{array}$ & & \\
\hline 2 & $\begin{array}{l}\text { I believe that I have many } \\
\text { strengths in Mathematics. } \\
\text { Compared to other students, }\end{array}$ & 3.32 & 1.013 \\
\hline 3 & $\begin{array}{l}\text { I am a smart student in } \\
\text { Mathematics. }\end{array}$ & 2.97 & 0.875 \\
\hline 4 & $\begin{array}{l}\text { Mathematics is one of my } \\
\text { strengths. }\end{array}$ & 3.10 & 1.106 \\
\hline 5 & $\begin{array}{l}\text { I usually can help my } \\
\text { classmates when they ask } \\
\text { me for help in problem- } \\
\text { solving. }\end{array}$ & 3.39 & 1.086 \\
\hline 6 & $\begin{array}{l}\text { I can usually solve any } \\
\text { mathematical problem. } \\
\text { I feel sure about myself in }\end{array}$ & 3.19 & 0.980 \\
\hline 7 & $\begin{array}{l}\text { solving Mathematical } \\
\text { problems. } \\
\text { When I start answering a }\end{array}$ & 3.19 & 0.873 \\
\hline 8 & $\begin{array}{l}\text { mathematical question, I } \\
\text { usually feel that I would } \\
\text { manage to give a solution. }\end{array}$ & 3.26 & 0.930 \\
\hline 9 & $\begin{array}{l}\text { I can easily understand } \\
\text { Mathematical problems. }\end{array}$ & 3.13 & 0.846 \\
\hline 10 & $\begin{array}{l}\text { I am capable of making } \\
\text { good grades in Math. }\end{array}$ & 3.45 & 1.150 \\
\hline & Overall Weighted $\mathrm{Mea}$ & & 3.18 \\
\hline & Overall Standard Devia & & \\
\hline
\end{tabular}

Classroom activities would not be enough to develop the skills of the students. With these, students need to extend their time doing math-related tasks at home. Self-efficacy refers to the extent to which students perceive their ability to succeed in the given tasks. If, based on experience, a student is not successful in a Mathematics class and encounters a problem that is not necessarily difficult, a student is likely to think, "I can't do this," and may almost immediately give up. The student believes that the work would be challenging to complete successfully because of his inability to do Brahier 2009 [8].

Table 6. Relationship between Time Management and Academic Performance $(n=31)$

\begin{tabular}{ccccc}
\hline Variables & $\boldsymbol{r}$ & $\boldsymbol{p}$-value & Decision & Remarks \\
\hline $\begin{array}{c}\text { Prioritization and } \\
\text { Performance } \\
\text { in Math }\end{array}$ & 0.252 & 0.172 & $\begin{array}{c}\text { Do not Reject } \\
\text { Ho }\end{array}$ & NS \\
$\begin{array}{c}\text { Procrastination and } \\
\text { Performance } \\
\text { in Math }\end{array}$ & 0.166 & 0.373 & $\begin{array}{c}\text { Do not Reject } \\
\text { Ho }\end{array}$ & NS \\
$\begin{array}{c}\text { Socialization and } \\
\text { Performance in Math }\end{array}$ & 0.094 & 0.613 & $\begin{array}{c}\text { Do not Reject } \\
\text { Ho }\end{array}$ & $\mathrm{NS}$ \\
\hline *significant at $p<0.05, \mathrm{NS}=$ Not Significont & & &
\end{tabular}

*significant at $p<0.05$, NS $=$ Not Significant

The three variables such as prioritization, procrastination, and socialization, were tested using at a 0.05 level of significance, as seen in Table 6 . The computed values of $r$ for prioritization ( $r=0.252)$, procrastination $(r=0.166)$, and socialization $(r=$ 0.094) signify that there is a negligible positive correlation between these variables and the academic performance of the respondents in math. Furthermore, with the computed $p-$ values of the test for prioritization $(p=0.172)$, procrastination ( $p=0.373)$, and socialization $(p=0.613)$ which are all greater than the significance level of 0.05 , the null hypotheses were rejected. The results suggest that the respondents' time management on the three variables has no bearing on their performance.

This finding is contrary to that of Abedayo 2015 [2], which revealed a significant relationship between time management described by the three variables: prioritization, procrastination, socialization, and academic performance. Moreover, Miqdadi et al. 2014 [21], in their study on the students of Petroleum Institute, found that time management is significantly related to their academic performance. However, this finding is consistent with Swart, Lombard, and Jager 2010 [43], which found no significant relationship between time management skills and African engineering students' academic achievement. The varied findings on this relationship could be explained by the different respondents involved in the study, just like the present study that considered the working students.

Table 7. Relationship between Self-efficacy and Academic Performance $(\mathrm{n}=\mathbf{3 1})$

\begin{tabular}{ccccc}
\multicolumn{4}{c}{ Academic Performance (n=31) } \\
\hline Variables & $\boldsymbol{r}$ & $\boldsymbol{p}$-value & Decision & Remarks \\
\hline $\begin{array}{l}\text { Self }- \\
\text { efficacy, and } \\
\text { performance } \\
\text { in Math }\end{array}$ & $0.468^{* *}$ & 0.008 & Reject Ho & Significant \\
\hline **significant at $p<0.01(2$-tailed $)$ & & & \\
\hline
\end{tabular}

It can be observed in Table 7 that the relationship between self-efficacy and academic performance of the respondents in math was tested using Pearson $r$. With the computed $r$-value of 0.468 , there is a weak positive correlation between the respondents' self-efficacy and their academic performance in math. Further, the calculated $p$ - value of 0.008 which is less than the significance level of $0.01(0.008<0.01)$, signifies that the null hypothesis is rejected. This finding suggests that the self-efficacy of the respondents has a bearing on their academic performance. It implies that as the respondents' level of self-efficacy increases, their academic performance also increases. When the respondents prioritize their studies and focus on what their subjects require from them, they will feel self-efficient towards their studies. They will feel contented with what they have done. These efforts that they have will be reflected in their grades. This study's finding is supported by Shkullaku 2012 [40] study, which found a significant relationship between the students' self-efficacy and academic performance. Consequently, Pajares 2000 [30] concluded that students who have higher self-efficacy beliefs perform better with their academic performance, not like the low-performing students who are hesitant to accomplish the tasks they consider to be difficult because of their lack of belief and abilities for success.

\section{Conclusion}

Time management of the working students does not affect their performance in math. However, it cannot be disregarded as a possible factor affecting their performance. because when 
this is considered, it could affect their performance, especially when these students have poor time management Balduf 2009 [6] although it has been observed that when students practice time management moderately, their performance will not be affected Miqdadi et al. 2014 [21]. On the other hand, the students' self-efficacy has a significant impact on their performance. Thus, students must improve their efficacy in studying mathematics to improve their performance. It is highly suggested that time management skills are integrated to shape and stimulate students' positive responses to pressures among all subjects. From the theoretical point of view, once the skills have been learned and put into practice, students are believed to manage their lives and endeavor more productively, and, as a result, their school and work objectives would be fulfilled

\section{References}

[1] Abouserie, R. (1995). Self-esteem and achievement motivation as determinants of students' approaches to studying. Studies in higher education , 20, 1926.

[2] Adebayo, F. (2015). Time Management and Students' Academic Performance in Higher Institution, Nigeria: A Case Study of Ekiti State. International Research in Education, 3(2): p. 1-11.

[3] Alay, S. \& Koçak, S. (2003). Relationship between timemanagement and academicachievement of university students. Kuram ve Uygulamada Eğitim Yönetimi Dergisi, 35, 326-335.

[4] Al Khatib, A. S. (2014). Time management and its relation to students' stress, gender and academic achievement among sample of students at Al Ain University of Science and Technology, UAE. International Journal of Business and Social Research (IJBSR), 4(5), p. 47 - 58

[5] Ayotola, A. \& Adedeji, T. (2009). The relationship between mathematics self-efficacy and achievement in mathematics. Procedia Social and Behavioral Sciences 1 (2009) 953-957.

[6] Balduf, M. (2009). Underachievement among college students. Journal of Advanced Academics, 20, 274-294.

[7] Bandura, A. (1995). Self-efficacy in Changing Societies.p.2

[8] Brahier, D. J. (2009). Teaching Secondary and Middle School Mathematics (Third Edition). Bowling Green University: Pearson Merrill Prentice Hall

[9] Brigitte, J. C., Claessens, Eerde, W. V., Rutte, C. G, Roe, R. A. (2005). A review of the Time management literature. Emerald Group Publishing Limited.
[10] Dinkel, A. M. (2011). Time management: Organization

andprioritizing.Available:https://www.laboratoryeq uipment.com/article /2011/04/time-managementorganization-and-prioritizing.

[11] Iz, FB \& Özen, T.A. (2010). Investigation of relationship between time

[12] Fazal, S. (2012), The Role of Study Skills in Academic Achievement of Students: A Closer Focus on Gender. Pakistan journal of Psychological research, 27 (1), p- 37-51.

[13] Gerard, M. (2002). Negative influences of time management. Available: http:// www.eskishore. Com/tiometips52.asp.

[14] Kearns, H., and Gardiner, M. (2007). Available: http://web.ebscohost.com/

[15] Khanam N, Sahu T, Rao EV, Kar SK, Quazi SZ(2017). A study on university student's time management and academic achievement. Int J Community Med Public Health ;4(12),4761-4765.

[16] Knaus, W. J. (1996). Procrastination. New York: Institute for Rational Therapy.

[17] Köseoğlu, Y. (2015). Self-Efficacy and Academic Achievement - A Case From Turkey. Journal of Education and Practice, 6(29), p. 131 - 141.

[18] Lane, J., \& Lane, A. M. (2001). Self-efficacy and academic performance. Social Behavior and Personality, 29, 687-694.

[19] Liu, X. and Koirala, H. (2009).The effect of mathematics self-efficacy on mathematics achievement of high school students. NERA Conference Proceedings 2009. 30.

[20] Mercanlioglu C. (2010). The Relationship of Time Management to Academic Performance of Master Level Students, International Journal of Business And Management Studies,2(1), p. 255-276.

[21] Miqdadi, F. Z., Momani, A. F., Masharqa, S.\& Elmousel, N. M. (2014).The Relationship between Time Management and the Academic Performance of Students from the Petroleum Institute in Abu Dhabi, the UAE. ASEE 2014 Zone I Conference, April 3-5, 2014, University of Bridgeport, Bridgpeort, CT, USA.

[22] Miller, R., \& Brickman, S. (2004). A model ofo future-oriented motivation and self-regulation. Educational Psychology Review, 16, 9-33.

[23] Misra, R.\&Mckean, M. (2000). College students academic stress and its relation to their anxiety, time management, and leisure satisfaction. American Journal of Health Studies, 16, 41-45.

[24] Mohamed, O., Hamal, R. B. \&Mohamed, K. (2016). A study on time management: case of Northeast Normal University international students. European 
Journal Of Alternative Education Studies, 3(1), p. $17-30$.

[25] Mousoulides, N., \& Philippou, G. (2005). Stu regulation strategies and mathematics achievement. In: H. L. Chick \& J. L. Vincent, eds, Proceedings of the 29th Conference of the International Group for the Psychology of Mathematics Education (PME),pp. 321-328.

[26] Muluk, S. (2017). Part-time job and students' academic achievement. Jurnal Ilmiah

[27] Nasiriyan, A., Azar, H. K., Noruzy, A., \& Dalvand, M. R. (2011). A model of self-efficacy, task value, achievement goals, effort, and mathematics achievement. International Journal of Academic Research, 3(2), 612-618.

[28] Nicolaidou, M., \& Philippou, G. (2003). Attitudes Towards Mathematics, Self Efficacy and Achievement in Problem-Solving. Available:http://fractus.uson.mx/Papers/CERME/T G2_draft/TG2_nicolaidou_corr.pdf

[29] Noftle, E., Robins., \& Richard, W. (2007). Personality predictors of academic outcomes: Big five correlates of GPA \& SAT scores. Journal of Personality and Social Psychology, 93, 116-130.

[30] Pajares, F. (2000). Against the odds: Self-efficacy beliefs of women in mathematical, scientific, and technological careers.\| American Educational Research Journal 37: 215-246.

[31] Pehlivan, A. (2013). The effect of the time management skills of students taking a financial accounting course on their course grades and grade point averages. International Journal of Business and Social Science, 4(5), p. 196 - 203.

[32] Quek, T. (2001). Procrastination. CEO Dexterity soft ware.

[33] Rai, A. (2016). A Study of Impact of Time Management on Academic Performance of Students Studying in School. PARIPEX - Indian Journal Of Research, 5(6): p. 149 -150.

[34] Sabelis, I. (2001), Time management: paradoxes and patterns. Time \& Society, 10, p- 387-400.

[35] Saketi P. \&Taheri A. (2010). The relationship between time management and academic achievements among bachelor and master students of Shiraz University and Shiraz University of Medical Sciences. Iranian Journal of Medical Education. 10 (3), 293-300.

[36] Sayari, K., Jalagat, R. \&Dalluay, V.(2017). Assessing the Relationship of Time Management and Academic Performance of the Business Students in Al-Zahra College for Women, European
Business \& Management, 3(1), 1-8. doi: 10.11648/j.ebm.20170301.11

[37] Schunk, D. H., \& Pajares, F. (2002). The development of academic self-efficacy. In A. Wigfield \& J. S. Eccles (Eds.), Development of achievement motivation, (pp. 15-31). San Diego, CA: Academic Press.

[38] Schwoerer, C.E., May, D.R., Hollensbe, E.C. and Mencl, J. (2005) General and Specific Self-Efficacy

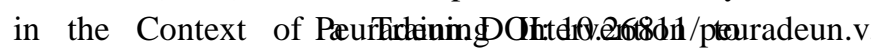
Enhance Performance Expectancy. Human Resource Development Quarterly, 16, 111-129.

[39] Sevari, K., \& Kandy, M. (2011). Time management skills impact on self-efficacy and academic performance. Journal of American Science, 7(12): p. 720-726.

[40] Shkullaku, R. (2012). The Relationship between Self - efficacy and Academic Performance in the Context of Gender among Albanian Students. European Academic Research, 1(4), p. 467 - 478.

[41] Sousa, V.D., Driessnack, M., \& Mendes, I.A.C. (2007). An overview of research designs relevant to nursing: Part 1: Quantitative research designs. Rev. Latino-Am. Enfermagem vol.15 no.3 Ribeirão Preto June $2007 . \quad$ Available: http://dx.doi.org/10.1590/S010411692007000300022

[42] Stajkovic, A.D. and Luthans, F. (1998) SelfEfficacy and Work-Related Performance: A MetaAnalysis. Psychological Bulletin, 124, 240-261.

[43] Swart, A. J., Lombard, K., \&Jager, H. (2010). Exploring the relationship between time management skills and the academic achievement of African engineering students - a case study. European Journal of Engineering Education, 35(1), 79-89.

[44] Tanriogen, A. \& Iscan, S. (2009). Time management skills of Pamukkale University students and their effects on academic achievement. Eurasian Journal of Educational Research, 35, 93 108.

[45] Yilmaz, İ., Yoncalik, O., \&Bektaş, F. (2010). Relationship between the time management behavior and academic success. E-Journal of New World Sciences Academy, 5(3), 187-194.. 